\title{
$\bullet \cdot$ \\ Review on Anti-Rheumatoid Arthritis Potential of Medicinal Plants
}

\author{
IJCRR \\ Section: Healthcare \\ ISI Impact Factor \\ (2019-20): 1.628 \\ IC Value (2019): 90.81 \\ $\operatorname{SJIF}(2020)=7.893$ \\ (c) (7) (8) \\ Copyright@IJCRR
}

Anjana Goel ${ }^{1}$, Sunanda Kulshrestha²

'Associate Professor, Department of Biotechnology, GLA University, Mathura, U.P, India; ${ }^{2}$ PhD Scholar, Department of Biotechnology, GLA

University, Mathura, U.P, India.

\section{ABSTRACT}

Autoimmunity is an immunological disorder in which immune response against self-antigens is provoked. Rheumatoid arthritis (RA) is one of its kinds of chronic autoimmune disorder causing inflammation and infiltration of immune cells around the synovial membrane, which leads to destruction and degradation of cartilages. Steroidal and non-steroidal allopathic therapies available so far cannot cure or prevent the disease. Besides their severe side effects, they can only provide temporary relief by suppressing and reducing the pain in the joints. Detailed search for the related literature has been carried out using multiple searches with words 'rheumatoid arthritis'; 'plants for rheumatoid arthritis' etc. with the help of search engines. Pubmed, Research Gate, Google Scholar have been used for more authentic information support. Alternative medicinal approaches for the treatment of Rheumatoid arthritis, as a holistic approach, can be used in a better way for making life much better for the sufferer and restricting the progression of the disease. Some of the approaches carrying ethanotraditional and ethnobotanical importance have been discussed in the review article and tried to assemble all possible plants that show Anti-Rheumatoid Arthritis activity. These approaches are giving some hope for the treatment of RA. The experimental model for investigating the effects of drugs on RA has also been discussed. This could draw a new pathway for future researches as well.

Key Words: Arthritis, Autoimmunity, Ayurveda, Immunological disorder

\section{INTRODUCTION}

Rheumatoid arthritis affects almost $0.5-1 \%$ of the population worldwide ${ }^{1}$ and in case of the Indian population, more than $20 \%$ of the population suffers from any of the forms of arthritis. ${ }^{2}$ It is a multifunctional immune disorder with a known cause. Some factors which may influence RA are a genetic factor, age, hormones, environmental factors, smoking etc. Different strategies for the study of RA have been used. Experimental animal model, which elucidate the onset and progression of the disease as well as evaluate the drugs that can reduce or prevent the disease, can be studied. An ideal model should have close similarities with human disease pathogenesis and symptoms. The use of an ideal animal model contributes significantly to the evaluation of therapeutic molecules against RA. ${ }^{3}$

\section{Causes}

RA is believed to be an autoimmune disorder, although the real cause and aetiology of the disease are still unknown. The frequency of appearance is three times more in the females rather than the males. ${ }^{4}$ RA sometimes also leads to diffused inflammations in the lungs, pleura and sclera, nodular lesions, and most commonly in the subcutaneous tissue, this is the most severe type of RA. Autoimmunity is known to be the major prognostic factor behind RA and plays important role in its progression towards severity. Inflammations in synovial joints are caused by many kinds of immune-mediated compounds. ${ }^{5}$ The cause is still not clear but the destruction of articular cartilage due to inflammatory responses is the major cause of RA. ${ }^{6}$

\section{Symptoms}

Symptoms for the same includes, joint pain and swelling, stiffness in joints, sleeplessness, fatigue, loss of weight and having flu kind of symptoms. Abnormal antibodies IgG have been found in the blood of a person suffering from rheumatoid arthritis. They react to antigens leading to the formation of antigen-antibody complex that leads to inflammation and pain of the synovial membrane. ${ }^{7}$

\section{Corresponding Author:}

Anjana Goel, Associate Professor, Department of Biotechnology, GLA University, Mathura, U.P., India Contact: 91 9897006326; Email: anjana.goel@gla.ac.in; anjanagoel2000@yahoo.com

ISSN: 2231-2196 (Print) ISSN: 0975-5241 (Online)

Received: $07.08 .2020 \quad$ Revised: 11.10 .2020

Accepted: 08.11 .2020

Published: 03.02 .2021 


\section{Diagnosis}

Diagnosis for RA involves the use of clinical methods of imaging and laboratory tests. Laboratory testing methods include anaemia, presence of rheumatoid factor, antibodies against the cyclic citrullinated peptides and elevation in erythrocyte sedimentation rate. While symptomatic detection of stiffness and pain for a long time in the morning gives some clue about the disease. X-rays also help in detecting the RA but at times they can't differentiate in early arthritis too. MRI and ultrasounds are also done to look at the progress of the RA in the patients. No such highly specified test has been developed for validation of the disease. ${ }^{8,9}$

\section{GENERAL TREATMENT FOR RHEUMATOID ARTHRITIS AND ITS LIMITATION}

Management of pain, prevention of long-term damage to the joints and reduction in inflammation are major problematic area to deal with while treating RA. For these, disease-modifying anti-rheumatic drugs (DMARDs) and non-steroidal anti-inflammatory drugs (NSAIDs) have been used as the major approaches to deal with the symptoms and after-effects of the disease. Other steroidal drugs that are used to treat inflammation by RA are corticosteroids, an anti-inflammatory hormone released from adrenal glands. An ideal steroid should meet the requirement of meeting the need at a low dosage and avoid side effects. Both the steroidal and non-steroidal drugs although control the symptoms but in long term, they cannot cure the disease or prevent it. Apart from all this, more severe side effects can be seen in the patients in terms of effects on kidney, liver and heart due to prolonged use to such medicines. Shortness of breath, nausea, infections and allergic reactions have also been noticed as the short-term side effects. This in turns marks the major limitation and issue while dealing with steroidal drugs for curing rheumatoid arthiritis. ${ }^{4}{ }^{10}$ They don't work effectively progression of the disease and cure it of its roots. They are just meant to deal with the symptoms like pain, inflammation, swelling etc. which are the main symptoms as discussed before.

\section{AYURVEDIC PERSPECTIVE OF RHEUMATOID ARTHRITIS}

Ayurveda is one of the forms of alternative treatment of medicine. It is typically based on three dosa: Vata, pitta and Kapha. Amavata, an ayurvedic condition has similarities with RA. ${ }^{11,12}$ Amavata is associated with the production of "Ama" in the gut. Ama is produced due to the disturbed metabolism. ${ }^{13,14}$ It is pro-inflammatory and creates toxicity in the gut and imbalance of Vata in the body. According to Ayurveda the people with Vata dosa are more prone to develop this disorder. ${ }^{11}$ Thus it can be cured by taking the diet which is rich in grains, legumes, green leafy vegetables, buttermilk etc. Spices like ginger, garlic and turmeric aid the digestion process and anti-inflammatory, thus recommended. Lukewarm water is always preferred for the digestion in Ayurveda. Ginger roots, boiled in water, also remove toxins from the body and help in the digestion process. The commonly used plants used to treat and mitigate the symptoms of RA have been summed up in table 1.

\section{NEED OF NATURAL REMEDIES}

Since time immemorial, the natural remedies used by the population has been helpful to meet the symptoms of any diseases or even used till date by many folks, tribal and traditional medicinal practitioners for treatment. According to WHO, $80 \%$ of the population still rely on herbal treatments. Plants and herbs have been taken in form of infusion, raw or juice form and have worked efficiently as per observation in the patients. Just with the inclusion of such plants with medicinal properties in daily diet made a tremendous change in the disease while benefiting the sufferer. This directly indicates that there is a world to explore in the field of phytoconstituents of plants that have been used traditionally for curing RA.

\section{POSSIBLE MECHANISM OF ACTION OF HERB- AL DRUGS}

Many researchers have tried to elaborate a particular pathway of mechanism that the herbal drugs follow to hit the causative factors that are responsible for symptoms of RA and cure the disease from inside. As the disease progress via different mechanisms and pathways, therefore multi-pathway effects have been noticed by the herbal remedies by many researchers and some of them have been discussed below.

It has been observed that TLRs (toll-like receptors) play a major role in inflammation in RA and stimulate the cellular activity of NF- $\kappa \beta$ mediated by adapter molecules like myeloid differentiation primary-response gene 88 (MyD88) at the onset of disease. The process of phosphorylation of cytoplasmic I $\kappa \mathrm{Bs}$ is carried by TLR2/6, TLR4, or TLR5 agonist which in turn stimulate target cells and macrophages. After degradation of this complex, NF- $\kappa \beta$ translocated into the nucleus where the promoter regions of inflammatory genes like iNOS, COX-2, IL-6 bind to NF- $\kappa \beta$ for transcriptional activation. Augmentation in COX-2 and other pro-inflammatory cytokines modulate the metabolism of arachidonic acid which results in the formation of prostaglandins-E-2 and turn leads to suppression of leukocytes apoptosis and even stimulate proliferation of leukocyte which leads to the pathological condition of hyperplasia and pannus formation at the site. Therefore, it could be inferred why inhibition of $\mathrm{NF}-\kappa \beta$ would act as a major target for dealing with RA. ${ }^{15}$ 
Apart from this, cytokines and other pro-inflammatory factors play a protagonist progression of the disease. TNF- $\alpha$, IL$1 \beta$ and IL- 6 are the major pro-inflammatory cytokines which activate the collagenase and other proteases to degrade the collagen thus increases the degradation of cartilage. It also leads to an increase in the infiltration of T cell, B cell and macrophages causing synovial inflammation. It implies that the herbal drug should be capable to inhibit and inactivate such pathways and complexes. ${ }^{16}$ Many herbal drugs have shown to down-regulate these proinflammatory cytokines and reduce oxidative stress.

In this row plants like Saraca asoca, which is a commonly used plant having traditional use in RA has shown major anti-inflammatory activities in vivo model showing the reduced level of pro-inflammatory cytokines. ${ }^{16}$ Ocimum, which already holds many therapeutic potentials to its glory also acts on RA by showing anti-inflammatory activity by inhibition of arachidonate metabolism and anti-histaminic activity. Eugenol (1-hydroxy-2-methoxy-4-allylbenzene), which is one of the most active bioactive molecules of Ocimum, is playing a major role. ${ }^{17}$ Cannabis sativum, a notorious plant is known for its addictive properties is also been tested for RA and gave results in favour of it. The cannabidiol, a major constituent of the plant is shown to act for anti-inflammatory by inhibiting COX-2 in mice model. ${ }^{18}$ Similar activity of suppression of NF- $\kappa \beta$ pathway and COX-2 has been seen by aerial parts of Cassia plant which has also been one of the important traditional medicine for treating RA. The leaves have been found experimentally to show results for swelling, improvement in cartilage degradation and leucocyte infiltration in synovial fluid in the rat model study. ${ }^{19}$ Similar activities have been noted in Zingiber officinale which seen to possess a bioactive constituent 6-gingerol, that blocks the $\mathrm{NF}-\kappa \beta$ and $\mathrm{PKC}$ (protein kinase $\mathrm{C}$ ) pathway and induce antiinflammatory activity. ${ }^{20}$ Another remedy used Semecarpus Anacardium which is a tree from the sub-Himalayan region is seen to be effective in RA and has anti-oxidant potential proved by inhibition of ROS in the body. The flavonoids also induce anti-inflammatory action by inhibition of phospholipase $\mathrm{A} 2$ that reduces the production of PGE2 and also reduce the level of TNF- $\alpha$ and NO. This all helps in preventing the rupture and release of lysosomal enzyme and help in synovial erosion. ${ }^{21}$

Artemisia absinthium, a Persian plant is also used as a traditional plant for curing RA and is seen to suppress inflammatory diseases by following multiple pathways. It acts by reducing the release of $\mathrm{NO}$ and PGE2 which inhibits the iNOS expression. Also, another pathway followed includes inhibition of COX-2 expression by scoparone, a bioactive compound found in the plant. Similar multi-path action is also exhibited by A. sylvatica Maxim aerial parts. ${ }^{22}$ Experimental studies have also supported the use of Curcuma lon$g a$, a widely used spice containing curcumin. It inhibits the arachidonic acid cascade by the mode of inhibition of catalytic activities of phospholipases and blocking the catabolic effect of IL-1 $\beta$ induced upregulation of MMP-3, and IL$1 \beta$-induced decrease in type II collagen synthesis which is a contributing factor in RA progression. ${ }^{23}$ Other plants including Moringa oleifera which shows anti-inflammatory effect by lowering down serum levels of Rheumatoid Factor (RF) and levels of the cytokines, TNF- $\alpha$ and IL-124, Nyctanthes arbor-tristis which lowers down the inflammatory cytokines IL-1, TNF- $\alpha$ in blood serum in experimental set up ${ }^{25}$, Swertia chirayita, works in similar style and lowers down the proinflammatory cytokines IL- $1 \beta$, TNF- $\alpha$ and IL- 6 in experimental arthritis ${ }^{26}$ have been found to act effectively on RA following multiple pathways.

Minimal or no side effects by these remedies are the best part of the approach. After prolonged use of allopathic drugs, many side effects have been observed in the patients of RA as listed above. Hence, herbal therapies could act as effective approaches towards the treatment of such diseases. Today, uses of many phytomedicinal plants have been observed by experimental methods and are under scientific observations to develop as a natural way for healing. ${ }^{27}$ Goals of natural therapy includes a reduction in joint pains, prevention of deformity, prevention of erosion, prevention from progression, control on extra-articular manifestations while maintaining the quality of life as well..$^{6,7,28}$ Medicinal plants which have been tested experimentally and proven their efficacy are represented in tabular form in table 2. Using suitable experimental protocols related to in vitro and in vivo validations of anti-inflammatory effects, positive results has been observed that supports the ethnobotanical importance of herbal remedies for dealing with rheumatoid arthritis and lays an important source for future researches as well.

\section{CONCLUSION}

Rheumatoid arthritis is an autoimmune disease and well known for causing deformities and pain due to inflammations in the joints of the sufferer. Conventionally, the allopathic approaches used to treat RA comprise on disease-modifying anti-rheumatic drugs, Non-steroidal anti-inflammatory drugs and corticosteroids, which relieve the pain and inflammation till a limited time when they are in action. They are also accountable for some side effects in the patients and never show or promise to cure the disease from within. Looking at all the perspectives, the herbal approach can be thought of as an alternative approach for the treatment of RA. Our folk and indigenous treasure of knowledge hold many secrets to cure any diseases without causing any side effects. At present herbal remedies carrying anti-arthritic activities have been developed and potentials of their phytochemicals continuously have been validated. More than 450 species of plants have been listed that promise anti-arthritic activity 
in humans ranging from various plant families. The article summarizes data regarding plants that could help and motivate researches in future.

\section{ACKNOWLEDGEMENTS}

Authors acknowledge the immense help received from the scholars whose articles are cited and included in references to this manuscript.

\section{Conflict of Interest: Nil}

Source of Funding: Nil

\section{REFERENCES}

1. Gabriel SE, Kaleb M. Epidemiological studies in incidence, prevalence, mortality, and comorbidity of the rheumatic diseases. Arthritis Res Ther 2009;211:29.

2. Patwardhan SK, Bodas KS, Gundewar SS. Effect of Facetal Joint Mobilization In Lumbar Spondylosis. Int J Pharm 2010;10:216-218.

3. Mohanad JK, Hameed IH, Kaizal AF, Medicinal Plants Used for Treatment of Rheumatoid Arthritis: A Review. Int J Pharma Clin Res 2016;8:1685-1694.

4. http://arthritis.ca/getmedia/6c39edce-5b2d-498d-bd60 28d33f3e1850/Rheumatoid-Arthritis-Causes-Symptoms-and Treatments.pdf?ext=.pdf

5. Majithia V, Geraci SA. Rheumatoid arthritis: diagnosis and management. Am J Med 2007; 120:936-939.

6. Smolen JS, Steiner G. Therapeutic strategies for Rheumatoid arthritis. Nature Rev Drug Discov 2003;2:473-488.

7. Shivanand P, Arthritis an autoimmune disorder: Demonstration of In-vivo anti-arthritic Activity. Int J Pharm Life Sci 2010;1:38-43.

8. Rindfleisch JA, Muller D. Diagnosis and management of rheumatoid arthritis. Am Fam Physician 2005;72:1037-1047.

9. Nadkarni KM, Nadkarni AK. Indian materia medica: with Ayurvedic, Unani-Tibbi, Siddha, allopathic, homoeopathic, naturopathic \& home remedies, appendices \& indexes. Bombay, India, Poupular Pakashan Pvt. Ltd. 2009.

10. Chandrasekar R, Chandrasekar S. Natural herbal treatment for Rheumatoid Arthritis - A review. Int J Pharma Sci and Res 2017;8:368-384.

11. Srikantha MKR, Madhava N. (roga viniscaya) of Madhavakara (English translation), Chapter 22. Delhi: Chaukhambia Orientalia 1993.

12. MOHFW. Department of Indian Systems of Medicine and Homeopathy. Ayurvedic Pharmacopeia of India, , Ministry of Health and Family Welfare, Government of India, 2001 (1).

13. Sharma PV. Charaka Samhita (English translation). Chikitsa Sthana, Chapter 28. Delhi: Chaukhambia Orientalia 1994.

14. Chopra A, Saluja M, Tillu G. Ayurveda-modern medicine interface: a critical appraisal of studies of Ayurvedic medicines to treat osteoarthritis and rheumatoid arthritis. J Ayur Integra Med 2010;1:190-198.

15. Shen H, Tesar BM, Walker WE and Goldstein DR. Dual signaling of MyD88 and TRIF is critical for maximal TLR4- induced dendritic cell maturation. J Immuno 2008;3:1849-1858.

16. Saravanan S, Prakash B, Pandikumar P, Ignacimuthu S. Therapeutic effect of Saraca asoca (Roxb.)Wilde on lysosomal en- zymes and collagen metabolism in adjuvant induced arthritis. Inflammopharmacology 2011;19:317-25.

17. Goel A, Singh DK, Kumar S, Bhatia AK. Immunomodulating property of Ocimum sanctum by regulating the IL-2 production and its mRNA expression using rat's splenocytes. Asian Pac J Trop Med 2010;3:8-12.

18. Rathore B, Mahdi AA, Paul BN, Saxena PN, Das SK. Indian herbal medicines: possible potent therapeutic agents for rheumatoid arthritis. J Clin Biochem 2007;41:17-9.

19. Lewis, A. and Levy, A. Anti-inflammatory activities of Cassia alata leaf extract in complete Freund's adjuvant arthritis in rats. West Indian Med J. 2011;60:615-21.

20. Al-Nahain A, Jahan R, Rahmatullah M. Zingiber officinale: A Potential Plant against Rheumatoid Arthritis. Arthritis 2014; 159089:8

21. Pandey P, Tiwari S. Therapeutic Potential of Indian Plants for the Treatment of Rheumatoid Arthritis. J Pharmacog Phytochem 2018;7:37-41

22. Tripathy S, Pradhan D, Anjana M. Antiinflammatory and antiarthritic potential of Ammania baccifera Linn. Int J Pharma Bio Sci 2010;1:1-7.

23. Kukar M. Complementary and alternative medicine use in rheumatoid arthritis: proposed mechanism of action and efficacy of commonly used modalities. Rheumatol Int 2010;30:571-586.

24. Mahajan SG, Mehta AA. Immunosuppressive activity of ethanolic extract of seeds of Moringa oleifera Lam. in experimental immune inflammation. J Ethnopharmacol 2010;130(1):183186.

25. Paul BN, Saxena AK. Depletion of TNF- $\alpha$ in mice by Nyctanthes arbortristis. J Ethnopharmacol 1997;56:153.

26. Kumar IV, Paul BN, Asthana A, Saxena A, Mehrotra S, Rajan G. Swertia chirayita mediated modulation of IL-1 $\beta$, IL-6, IL10, IFN- $\gamma$ and TNF- $\alpha$ in arthritic mice. Immunopharmacol Immunotoxicol 2003;25:573-83.

27. Sharma J, Painuli RM. Plants used for the treatment of Rheumatism by the Bhoxa tribe of Dis-trict Dehradun, Uttarakhand, India. Int J Med Arom Plants 2011;1:28-32.

28. Rathore B, Mahdi AA, Paul BN, Saxena PN, Das SK. Indian herbal medicines: possible potent therapeutic agents for rheumatoid arthritis. J Clin Biochem 2007;41:17-9.

29. Vijaykumar M K, Ajay G. Namdeo antiarthritic effect of galanin isolated from rhizomes of Alpinia officinarum in complete Freund's adjuvant-induced arthritis in rats. Int J Pharm Pharm Sci 2012;6:499-505.

30. Usmani A, Khushtar M, Arif M, Mohd. Siddiqui AS, Sing SP, Md M. Pharmacognostic and phytopharmacology study of Anacyclus pyrethrum: An insight. J App Pharma Sci 2016;6:144-150.

31. Mokarram M, Biva IJ, Jahangir R and Mynol IV. Central nervous system depressant and analgesic Activity of Aphanamixis polystachya (Wall.)Parker leaf Extract in mice. Afr J Pharm Pharmacol 2009;3:282-6.

32. Rahman H, Eswaraiah M C, Dutta AM. Anti-arthritic activity of leaves and oil of Aquilaria agallocha. Saudi J Life Sci 2016;1:34-3.

33. Rajvaidhya, S, Nagori BP, Singh, GK, Dubey BK, Desai, P and Jain S. A review on Argemone mexicana Linn. An Indian medicinal plant. Int J pharma Sci Res 2012;3:2494-2501.

34. Yadav V, Jayalakshmi S, Patra A, Singla RK, Patra A, Khan S. Assessment of anti-inflammatory and analgesic activities of Callicarpa macrophylla Vahl. roots extracts. Web Med Central Pharmacol 2012;3:WMC003366.

35. Marwat SK, Fazal UR, Usman K, Khakwani AA, Ghulam S, Anwar N, Sadiq M \& Khan SJ. Medico-Ethnobotanical 
Studies of Edible Wild Fruit Plant Species from the Flora of North-Western Pakistan, D.I. Khan District. J Med Plant Res 2011;5:3679-3686.

36. Venkatesh Babu KC and Krishnakumari S. Cardiospermum halicacabum suppress the production of TNF-alpha and Nitric oxide by Human Peripheral Blood Mononuclear Cells. Afr J Biomed Res 2006;9:95-9.

37. Ramachandran J, Thilagar S, Angappan R, Lakshmanan DK. Anti-arthritic activity of the Indian leafy vegetable Cardiospermum halicacabum in Wistar rats and UPLC-QTOF-MS/ MS identification of the putative active phenolic components. Inflamm Res 2013;62:115-126.

38. Jun MS, Ha YM, Kim HS, Jang HJ, Kim YM, Lee YS, et al. Anti-12. Inflammatory action of methanol extract of Carthamus tinctorius involves in heme oxygenase-1 induction. J Ethnopharmacol 2011;133:524-530.

39. Jinous ANK. Phytochemistry, pharmacology and medicinal properties of Carthamus tinctorius L. Chinese J Integrative Med 2013;19:153-159.

40. Sheikh NW, Patel RD, Upwar NI, Mahobia NK, Seth PMV. Analgesic study of methyl alcohol extract of Cassia fistula Pod. J Pharm Res 2010;3:2218-2229.

41. Varadharajan M, Sunkam Y, Magadi G, Rajamanickam De, Deepti R, Vedavathi A. Pharmacognostical studies on the root bark and stem bark of Catunarega Spinosa (Thunb.) Tiruv. (Madanaphala) - an Ayurvedic drug. Spatula DD 2014;4:89-9.

42. Akhzari M, Mirghiasi SM, Vassaf M, Bidgoli MSM, Tari ZS. The Effect of Citrullus Colocynthis on the Reduction of Inflammatory Agents in Osteoarthritis. Mol Biol 2015;4(4):1000147.

43. Shen T, Li GH, Wang XN, Lou HX The genus Commiphora: a review of its traditional uses, phytochemistry and pharmacology. J Ethnopharmacol 2012;142:319-30.

44. Prerna S, Suman B, Kamboj S. Pharmacology and Phytochemistry of Oleo-Gum Resin of Commiphora wightii (Guggulu). Scientifica 2015;138039:

45. Shahapurkar AA, Jayanthi Drug. neomycin release from Cordia dichotoma transdermal film and anti-inflammatory activity. Int Res J Pharm 2011;2:107-109.

46. Mohan NPV, Suganthi VGS. Evaluation of anti-inflammatory activity in ethanolic extract of Coriandrum sativum L. using carrageenan-induced paw oedema in albino rats. Der Pharma Chemica 2013;5:139-143.

47. Papiya B, Faraz S. Anti-inflammatory and anti-arthritic effect of triterpene fraction isolated from Euphorbia neriifolia L. leaf. J Ethnobiol Trad Med.2015;241:1007-17.

48. Papiya B, Rana AC. A Comprehensive Phyto-pharmacological Review of Euphorbia neriifolia. Linn. Pharmacogn Rev 2008;2:57-66.

49. P Deka, KK Nath SK Borthakur. Ethoiatrical uses of Euphorbia antiquorum L. and E. ligularia Roxb. in Assam. Indian J Tradit Know 2008;7:466-468.

50. Bhardwaj LK, Chandru KK, Sharma US. Evaluation of Antiarthritic activity of Ficus benghalensis Linn. root extracts on Freund's adjuvant-induced Arthritis in rats. J Phytopharmacol 2016;5:10-14.

51. Shah WA, Mir TA, Ahmed A. Antiproliferative and Antioxidant potential of different extracts of Fritillaria roylei. World J Pharm Sci 2014;2:386-389.

52. Mohammed R, Rownak J, Azad AK, Syeda S, Mahbubur R, Anita RC, Rahima B, Dilruba N, Zubaida K, Mohammad SH, Afsana K, Emdadullah M. A randomized survey of medicinal plants used by folk medicinal practitioners in six districts of Bangladesh to treat rheumatoid arthritis. Adv Nat Appl Sci 2010;4:124-127.
53. Indian medicinal plants: a compendium of 500 species. $3 \mathrm{rded}$ Orient Longman Ltd; 2001. Pg 100-103.

54. Osungunna, MO and Adedeji KA. Phytochemical and antimicrobial screening of methanol extract of Heliotropium Indicum leaf. J Microbiol Antimicrobial 2011;3:213-216.

55. Ganguly A. Normalization of Varus/Valgus Deformities in Osteoarthritis by External Application of Phytoconstituents: Confirmed With Anatomical Observations and Biochemical Profiles and Radiological Images. Anat Physiol 2016;6:224.

56. Santanu S and Subrahmanyam EVS. Evaluation of AntiInflammatory Activity of Ethanolic Extract of Seeds of $\mathrm{Hol}$ arrhena Pubescens (buch.-ham.). Int J Pharm Pharm Sci 2013;5:915-9.

57. Dattatrya N, Shreekant M, Mishra D. Kokilaksha: A potential Ayurvedic Herb. Int J Res Ayur Pharm 2012;3:780-782.

58. Billore KV, Yelne MB. Denis T J. Database on Medicinal Plants Used in Ayurveda. New Delhi: Central Council for Research in Ayurveda \& Siddha 2005;7:320.

59. Wang GW, Hu WT, Huang BK, Qin LP. Illicium verum: A Review on its botany, traditional use, chemistry and pharmacology. J Ethnopharmacol 2011;136:10-20.

60. Arumugam P, Murugan M N T. Evaluation of anti-inflammatory and analgesic effects of the aqueous extract obtained from root powder of Inula Racemosa Hook. f. J Medi Plants Res 2012;6:2801-2806.

61. Ferreira AA, Amaral FA, Duarte IDG, Oliveira PM, Alves RB, Silveira D, Azevedo AO, Raslan DS, Castro MSA. Antinociceptive effect from Ipomoea cairica extract. J Ethnopharmacol 2006;105:148-153.

62. Yan WX, Zhang JH, Zhang Y, Meng DL, Yan D. Anti-inflammatory activity studies on the stems and roots of Jasminum lanceolarium Roxb. J Ethnopharmacol 2015;2:335-341.

63. Rachmani BS. Jatropha curcas leaves exert anti-arthritic activity on adjuvant-induced arthritis in rats. Universal Med 2014;33:1-8.

64. Lokar LC, Poldini L. Herbal remedies in the traditional medicine of the Venezia Giulia Region (North-East Italy). J Ethnopharmacol 1988;22:231-279.

65. Hosseinzadeh H, Zarei H, Taghiabadi E. Antinociceptive, AntiInflammatory and Acute Toxicity Effects of Juglans Regia L. Leaves in Mice. Iran Red Crescent Med J 2011;13:27-33.

66. Paval J. Anti-Arthritic Potential of the Plant Justicia Gendarussa. Burm F Clinics 2009;64:357-360.

67. Umar MI. Bioactivity-guided Isolation of Ethyl- $p$ methoxycinnamate, an Anti-inflammatory Constituent, from Kaempferia galanga L. Extracts. Molecules 2012;17:8720-8734.

68. Rohit G, Sheeba DSH, Ramesh C. Evaluation of Anti-Arthritic Effects of lantana camera var linn. Using Acute Model on Albino Rats. Int J Adv Pharmac Sci 2012;3:272-277.

69. Kore KJ, Shete RV, Desai NV. Anti-Arthritic activity of Hydroalcoholic extract of Lawsonia Innermis Int J Drug Dev Res 2011;3(4):217-224.

70. Jain, SK. Dictionary of Indian folk medicine and ethnobotany. New Delhi: Deep Publications. 1991.

71. Prashanth S, Kumarb AA, Madhub B and Yennamaneni PK. Antihyperglycemic and antioxidant activity of ethanolic extract of Madhuca longifolia bark. Int J Pharma Sci Rev Res 2010;5:89-94.

72. Hasbarinda BH. Chemical constituents of the twigs of Mangifera indica. Indo Am J 2008;23:1-3.

73. Vaidhyrathnam PV. Indian medicinal plants compendium of 500 species, Arya vaidya sala, Kottakkal, 4, 1996,882.

74. Roshan P, Naveen M, Nitin U, Naheed W, Hetal T, Zalak P. Analgesic and antipyretic activities of Momordica charantia Linn. Fruits. J Adv Pharma Technol Res 2010;1:415-418. 
75. Sheelarani.T, Gopal, V, Seethalakshmi S, Chitra K in Vitro Anti Inflammatory and Anti Arthritic Activity of Selected Medicinal Plant. Int J Pharm Sci Rev Res 2014;28:162-171.

76. Sreeshma PS, Regi Raphael K, Alby Alphons B. Pharmacognostic Studies of leaves of Naravelia Zeylanica (Linn) DC. South. Indian J Bio Sci 2016;2:179-182.

77. Khare CP. Indian Medicinal plants: An illustrated dictionary. Springer Publication, 2008;1:1-440.

78. Phadtare S, Pandit R, Shinde V, Mahadik K. Comparative Phytochemical and Pharmacological Evaluations of Two Varieties of Ocimum Basilicum for Antiarthritic Activity. J Pharmacog Phytochem 2013;2:58-167.

79. Zaveri M, Sunita J. Anti-inflammatory and analgesic activity of root bark of Oroxylum Indicum. J Glob Pharma Tech 2010;2:79 87.

80. R. Londonkar, A. Kamble, and V. C. Reddy. Anti-inflammatory activity of Pandanus odoratissimus extract, Int J Pharmacol 2010;6:311-314.

81. Agarwal T, Singh R, Shukla AD, Waris I, Gujrati A. Comparative analysis of the antibacterial activity of four Piper betle varieties. Adv App Sci Res 2012;3:698-605.

82. Jun SB, Da HO et al. Anti-inflammatory and antiarthritic effects of piperine in human interleukin $1 \beta$-stimulated fibroblastlike synoviocytes and rat arthritis models. Arthritis Res Ther 2009;11:49.

83. Ghani A, Medicinal Plants of Bangladesh, 2nd Ed. Asiatic Society of Bangladesh, Dhaka 2003;351-2.

84. Singh D, Nainwani R, Sharma, Gautam T R K. In-Vitro AntiInflammatory and Anti-Arthritic Activity of Hydroalcoholic Extract of Pongamia Pinnata (L.) Pierre Seed. Int J Pharma Res Rev 2013;2:20-25.

85. Gautam Rk., Sharma S, Sharma K. comparative evaluation of the anti-arthritic activity of Pongamia pinnata (Linn.) Pierre and Punica granatum Linn. : An in -vitro study. Int J Pharm Pharm Sci 2013;5:721-724.

86. Karthikeyan M, Deepa K. Effect of ethanolic extract of Premna corymbosa (Burm. f.) Rottl. \& Willd. Leaves in complete Freund's adjuvant-induced arthritis in Wistar albino rats. J Basic Clin Physiol Pharmacol 2010;21:15-26.

87. Ilavarasan R, Mallika M, Venkataraman S. Anti-inflammatory and free radical scavenging activity of Ricinus communis root extract. J Ethnopharmacol 2006;103:478-480.

88. Shekhar TC, Bahuguna YM, Singh V. Anti-inflammatory activity of ethanolic stem extracts of Rubia cordifolia Linn. in rats. IJRAP 2010;1:126-130.

89. Ageel AM, Mossa JS, AL-Yahya, M.A. Experimental studies on antirheumatic crude drugs used in Saudi traditional medicine. Drug Exp Clin Res 1989;15:369-372.

90. Polireddy D M. Evaluation of Anti-Arthritic Activity of Ethanolic Extract of Sida Cardifolia. Int J Sci Tech Res 2015;4:8696.

91. Zakaria ZA, Gopalan HK, Zainal H. Antinociceptive, antiinflammatory and antipyretic effects of Solanum nigrum chloroform extract in animal models. Yakugaku Zasshi 2006;126:1171-1178.

92. Keawsaard S, Liawruangrath B. Antimicrobial Activity of Spondias pinnata Kurz. PACCON. Pure and Applied Chemistry International Conference; 2009.

93. S. Latha, S. Seethalakshmi, D. Chamundeeswari and R. Senthamarai. Comparison of In-vitro Antiarthritic Activity of Stereospermum Colais \& Stereospermum Suaveolens. Int J Phytopharm Res 2015;6:59-60.

94. Scartezzini P, Speroni E. Review on some plants of Indian traditional medicine with antioxidant activity. J Ethnopharmacol 2000;71:23-43.
95. Sadiq UM, Mir S, Ansari MM, Hussain U, Ahmad W, Siddiqui S A, Sayeed A, Haider A. Khan Anti-inflammatory and antioxidant activity of Trachyspermum Ammi seeds in collageninduced arthritis in rats. Int J Drug Dev Res 2012;4:94-96.

96. Chaturvedi GN, Singh RH. Experimental studies on the antiarthritic effect of certain indigenous drugs.Ind J Med Res 1965;53:71.

97. Hansal R, Leuckert C, Rimpler H, Schaaf KD. Chemotaxomic investigation of the genus Vitex L. Phytochemistry 1965;4:19.

98. Muhammad SAB, Rana Md. S Rahmatullah M. Preliminary Phytochemical Screening of Five Plant Parts used in Bangladesh for Treatment of Rheumatoid Arthritis. Adv Nat Appl Sci 2015;9:15-21.

99. Ananda D, Karthic A, Lakshmi. T. In vitro Anti Arthritic Activity of Grape Seed Ethanolic Extract. Int J Pharmacog Phytochem Res 2015;7:977-979.

100. Gokhale AB, Damre AS, Kulkami KR, Saraf MN. Preliminary evaluation of anti-inflammatory and anti-arthritic activity of $S$. lappa, A. speciosa and A. Aspera. Phytomedicine 2002;9:433437.

101. Manjunatha BK, Abhilasha N, Hedge V, Suchitra MN, Vidya SM. Hepatoprotective potency of Achyranthes Aspera: An invitro study. Int J Pharm Phytopharm Res 2012;1:387-390.

102. Li M, He J, Jiang LL, Ng ES, Wang H, Lam FF, et al. The anti-arthritic effects of Aconitum vilmorinianum, a folk herbal medicine in Southwestern China. J Ethnopharmacol 2013;147:122-127.

103. Chandel S, Bagai U. Antiplasmodial activity of Ajuga bracteo$s a$ against Plasmodium berghei infected $\mathrm{BALB} / \mathrm{c}$ mice. Indian J Med Res 2010;131:440-4414.

104. Ono Y, Fukaya Y, Imai S, Yamakuni T. Beneficial effects of Ajuga decumbens on osteoporosis and arthritis. Biol Pharm Bull 2008;31:1199-204.

105. Olajide OA, Awe SO, Makinde JM, Ekhelar AI, Olusola A, Morebise $\mathrm{O}$, et al. Studies on the anti-inflammatory, antipyretic and analgesic properties of Alstonia boonei stem bark. J Ethnopharmacol 2000;71:179-186.

106. Kalaria P, Gheewala P, Chakraborty M, Kamath J. A phytopharmacological review of Alstonia scholaris A panoramic herbal medicine. Int J Res Ayur Pharm 2012;3:367-371

107. Tripathy S, Pradhan D, Anjana M. Anti-inflammatory and antiarthritic potential of Ammania baccifera Linn. Int J Pharm Bio Sci 2010;1:1-7.

108. Chitme HR, Malipatil M, Chandrashekhar VM, Prashant PM. Anti-allergic activity of Aristolochia bracteolata Lank in the animal model. Indian J Exp Biol. 2010;48:46-52.

109. Kamaljeet, Tomar S, Thakur N. Antipyretic activity of whole aerial part from Argyreia nervosa. Int J Pharm Pharm Sci 2012;4:1-2

110. Chunxia C, Peng Z, Huifang P, Hanli R, Zehua H, Jizhou W. Extracts of Arisaema rhizomatum C.E.C. Fischer attenuate inflammatory response on collagen-induced arthritis in BALB/c mice. J Ethnopharmacol 2011;133:573-582.

111. Fan H, Yang M, Che X, Zhang Z, Xu H, Liu K, et al. Activity study of a hydroxyl naphthoquinone fraction from Arnebia euchroma in experimental arthritis. Fitoterapia 2012; 83:12261237.

112. Ngoc DD, Catrina AI, Lundberg K, Harris HE, Ha NT, Anh PT, et al. Inhibition by Artocarpus tonkinensis of the development of collagen-induced arthritis in rats. Scand J Immunol 2005;61:234-241.

113. Babushetty V, Sultanpur MC. Evaluation of anti-arthritis activity of Asystasia dalzelliana leaves. Int J Pharma Biol Arch 2012;3:377-382. 
114. Coelho MG, Reis PA, Gava VB, Marques PR, Gayer CR, Laranja GA, et al. Anti-arthritic effect and subacute toxicological evaluation of Baccharis genistelloides aqueous extract. Toxicol Lett 2004;154:69-80.

115. Vijayan V, Shyni GL, Helen A. Efficacy of Bacopa monniera (L.) Wettst in alleviating lysosomal instability in adjuvant-induced arthritis in rats. Inflammation 2011;34:630-636.

116. Mazumder MP, Mondal A, Sasmal D, Arulmozhi S, Rathinavelusamy P.Evaluation of antiarthritic and immunomodulatory activity of Barleria lupulina. Asian Pac J Trop Biomed 2012;2:1400-1406.

117. Singh B, Bani S, Gupta DK, Chandan BK, Kaul A. Anti-inflammatory activity of 'TAF' an active fraction from the plant Barleria prionitis Linn. J Ethnopharmacol 2003;85:187-193.

118. Rajkapoor B, Ravichandran V, Gobinath M, Anbu J, Harikrishnan N, Sumithra M, et al. Effect of Bauhinia variegate on complete Freund's adjuvant-induced arthritis in rats. J Pharmcol Toxicol. 2007;2:465-472.

119. Bodakhe SH, Ram A. Hepatoprotective properties of Bauhinia variegata bark extract. Yakugaku Zasshi. 2007;127:15031507.

120. Nazir N, Koul S, Qurishi MA, Taneja SC, Ahmad SF, Bani S, et al. Immunomodulatory effect of bergenin and norbergenin against adjuvant-induced arthritis - a flow cytometric study. J Ethnopharmacol 2007;112:401-405.

121. Dapurkar KV, Sahu KG, Sharma H, Meshram S, Rai G. Antiarthritic activity of roots extract of Boerhaavia Diffusa in adjuvant-induced arthritis rats. Sch Acad J Pharm 2013;2:107-109.

122. Fan AY, Lao L, Zhang RX, Zhou AN, Wang LB, Moudgil KD, et al. Effects of an acetone extract of Boswellia carterii Birdw. (Burseraceae) gum resin on adjuvant-induced arthritis in lewis rats. J Ethnopharmacol 2005;101:104-109.

123. Muralidhar A, Babu KS, Sankar TR, Reddanna P, Latha J. Evaluation of wound healing properties of bioactive fractions from the extract of Butea monosperma (Lam.) stem bark. Int J Phytomed 2011;3:41-49.

124. Yerragunta V, Perusomula R, Bhangale J, Chaudhari R, Alluri R. Evaluation of anti-inflammatory and antiarthritic activity of Butea monosperma L. in laboratory animals. J Pharmacol Toxicol 2011;1:53-58.

125. Wu SQ, Otero M, Unger FM, Goldring MB, Phrutivorapongkul A, Chiari C, et al. Anti-inflammatory activity of an ethanolic Caesalpinia sappan extract in human chondrocytes and macrophages. J Ethnopharmacol 2011;138:364-372.

126. Saratha V, Subramanian SP. Lupeol, a triterpenoid isolated from Calotropis gigantea latex ameliorates the primary and secondary complications of FCA induced adjuvant disease in experimental rats. Inflammopharmacology 2012;20:27-37.

127. Kumar VL, Roy S. Calotropis procera latex extract affords protection against inflammation and oxidative stress in Freund's complete adjuvant-induced monoarthritis in rats. Mediators Inflamm 2007:47523.

128. Suszko A, Obminska-Mrukowicz B. Influence of polysaccharide fractions isolated from Caltha palustris L. on the cellular immune response in collagen-induced arthritis (CIA) in mice. A comparison with methotrexate. J Ethnopharmacol 2013;145:109-117.

129. Malfait AM, Gallily R, Sumariwalla PF, Malik AS, Andreakos E, Mechoulam R, et al. The nonpsychoactive cannabis constituent cannabidiol is an oral anti-arthritic therapeutic in murine collageninduced arthritis. Proc Natl Acad Sci 2000;97:9561.

130. Danquah AC, Woode E, Boakye-Gyasi E. Anti-arthritic effects of an ethanolic extract of Capparis erythrocarpus Isert roots in freund's adjuvant-induced arthritis in rats. J Pharmacol Toxicol 2011;6:201-207.
131. Feng X, Lu J, Xin H, Zhang L, Wang Y, Tang K. Anti-arthritic active fraction of Capparis spinosa $\mathrm{L}$. fruits and its chemical constituents. Yakugaku Zasshi 2011;131:423-429

132. Chaudhari SS, Chaudhari RS, Chavan JM. Analgesic, anti-inflammatory and anti-arthritic activity of Cassia uniflora Mill. Asian Pac J Trop Med 2012:181-186.

133. Escandell JM, Recio MC, Máñez S, Giner RM, Cerdá-Nicolás M, Ríos JL. Dihydrocucurbitacin B, isolated from Cayaponia tayuya, reduces damage in adjuvant-induced arthritis. Eur J Pharmacol 2006;532:145-154.

134. Ramachandran J, Thilagar S, Angappan R, Lakshmanan DK. The antiarthritic activity of the Indian leafy vegetable Cardiospermum halicacabum in Wistar rats and UPLC-QTOF-MS/ MS identification of the putative active phenolic components. Inflamm Res 2013;62:115-126.

135. Venkatesha SH, Yu H, Rajaiah R, Tong L, Moudgil KD. Celastrusderived celastrol suppresses autoimmune arthritis by modulating antigen-induced cellular and humoral effector responses. J Biol Chem 2011;286:15138-15146.

136. Chippada CS, Vangalapati M. Antioxidant, an anti-inflammatory and anti-arthritic activity of Centella asiatica extracts. J Chem Biol Physical Sci 2011;1:260-269.

137. Vetal S, Subhash LB, Vishwaraman M, Prasad AT. Anti-inflammatory and anti-arthritic activity of type-A procyanidine polyphenols from bark of Cinnamomum zeylanicum in rats. Food Sci Hum Wellness 2013;2:59-67.

138. Amresh, Reddy GD, Rao CV, Shirwaikar A. Ethnomedical value of Cissampelos pareira extract in experimentally induced diarrhoea. Acta Pharm 2004;54:27-35.

139. Lee YC, Kim SH, Roh SS, Choi HY, Seo YB. Suppressive effects of Chelidonium majus methanol extract in the knee joint, regional lymph nodes, and spleen on collagen-induced arthritis in mice. J Ethnopharmacol 2007;112:40-48.

140. Narendhirakannan RT, Subramanian S, Kandaswamy M. Antiinflammatory and lysosomal stability actions of Cleome gynandra L. studied in adjuvant-induced arthritic rats. Food Chem Toxicol 2007;45:1001-1012.

141. Nair V, Singh S, Gupta YK. Evaluation of the disease-modifying activity of Coriandrum sativum in experimental models. Indian J Med Res 2012;135:240-5.

142. Choudhary N, Kalita JC, Haque A. Effect of Costus speciosus Keon on the reproductive organ of female albino mice. Int Res J Pharm 2012;3:200-202.

143. Kokate CK, Purohit AP, Gokhale SB. Pharmacognosy. 43rd ed. New Delhi, India: Nirali Prakashan 2009.

144. Iwo MI, Soemardji AA, Retnoningrum DS, Sukrasno, Ur U M. Immunostimulating effect of pule (Alstonia scholaris) L. R.Br. Apocynaceae) bark extracts. Clin Hemorheol Microcirc 2000;23:177-183.

145. Murugananthan G, Mohan S. Anti-inflammatory and anti-arthritic activities of Delonix elata bark extracts. Int J Res Ayur Pharm 2011;2:1819-1821.

146. Jung HW, Jung JK, Son KH, Lee DH, Kang TM, Kim YS, et al. Inhibitory effects of the root extract of Dipsacus asperoides on collagen-induced arthritis in mice. J Ethnopharmacol 2012;139:98-103.

147. Kamboj P, Kalia AN. Hepatoprotective effect of Drynaria quercifolia Fronds hydroalcoholic extract and isolated constituent against CCl4-induced hepatocellular damge. Br J Pharm Res 2013;3:3563-78.

148. Ramasamy SK, Rajendran VK, Rangaraj RK, Chinnayan V, Palanisamy R, Prasannan D, et al. Effect of Elaeocarpus sphaericus in Freund's complete adjuvant-induced rheumatoid arthritis in albino rats. Indo Glob Res J Pharm Sci 2012;2:37882. 
149. Yeom MJ, Lee HC, Kim GH, Lee HJ, Shim I, Oh SK, et al. Anti-arthritic effects of Ephedra sinica STAPF herb-acupuncture: Inhibition of lipopolysaccharide-induced inflammation and adjuvant-induced polyarthritis. J Pharmacol Sci 2006;100:4150 .

150. Harpalani AN, Taranalli AD, Otari KV, Karadi RV, Shete RV. An anti-inflammatory and anti-arthritic potential of aqueous and alcoholic extract of Euphorbia antiquorum Linn. Pharmacology online 2011;2:287-98.

151. Manocha N, Chandra SK, Sharma V, Sangameswaran B, Saluja M. Anti-rheumatic and antioxidant activity of extract of stem bark of Ficus bengalensis. Res J Chem Sci 2011;1:2-8.

152. Han Y. Ginkgo terpene component has an anti-inflammatory effect on Candida albicans-caused arthritic inflammation. Int Immunopharmacol 2005;5:1049-56.

153. Ramesh RP, Vijaya C. Anti-diabetic and anti-arthritic potential of Glycosmis pentaphylla stem bark in FCA induced arthritis and streptozotocin-induced diabetic rats. Int J Pharm Bio Sci 2012;3:328-336.

154. Mishra NK, Bstia S, Mishra G, Chowdary AK, Patra S. Antiarthritic activity of Glycyrrhiza glabra, Boswellia serrata and their synergistic activity in combined formulation studied in Freund's adjuvant-induced arthritic rats. J Pharm Educ Res 2011;2:92-8.

155. Rai A. The anti-inflammatory and antiarthritic properties of ethanol extract of Herdera helix. Indian J Pharm Sci 2013;75:99-1

156. Perez RM, Perez S, Zavala MA, Salazar M. Anti-inflammatory activity of the bark of Hippocratea excelsa. J Ethnopharmacol 1995;47:85-90.

157. Perez RM, Perez S, Zavala MA, Salazar M. Anti-inflammatory activity of the bark of Hippocratea excelsa. J Ethnopharmacol 1995;47:85-90.

158. Tripathy S, Sahoo SP, Pradhan D, Sahoo S, Satapathy DK. Evaluation of the anti-arthritic potential of Hybanthus enneaspermus.Afr J Pharm Pharm 2009;3:611-614.

159. Paval J, Kaitheri SK, Potu BK, Govindan S, Kumar RS, Narayanan SN, et al. Anti-arthritic potential of the plant Justicia gendarussa Burm F. Clinics (Sao Paulo) 2009;64:357-362.

160. Gundamaraju R, Sheeba DS, Ramesh C. Evaluation of antiarthritic effects of Lantana Camara var Linn. using the acute model on albino rats. Int J Adv Pharm Sci 2012;3:272-277.

161. Luo X, Li LL, Zhang SS, Lu JL, Zeng Y, Zhang HY, et al. Therapeutic effects of total coumarins from Urtica dentata Hand on collagen-induced arthritis in Balb/c mice. J Ethnopharmacol 2011;138:523-529.

162. Kore KJ, Shete RV, Desai NV. Anti-Arthritic activity of hydroalcoholic extract of Lawsonia Innermis. Int J Drug Dev Res 2011;3:217-224.

163. Kripa KG, Chamundeeswari D, Thanka J, Uma Maheswara Reddy C. Modulation of inflammatory markers by the ethanolic extract of Leucas Aspera in adjuvant arthritis. J Ethnopharmacol 2011;134:1024-1027.

164. Kaithwas G, Majumdar DK. The therapeutic effect of Linum usitatissimum (flaxseed/linseed) fixed oil on acute and chronic arthritic models in albino rats. Inflammopharmacology 2010;18:127-136.

165. Lee JH, Han Y. Antiarthritic effect of lonicerin on Candida albicans arthritis in mice. Arch Pharm Res 2011;34:853-859.

166. Purushoth Prabhu T, Panneerselvam P, Vijaykumar R, Atlee $\mathrm{CW}$, Balasubramanian S. Anti-inflammatory, anti-arthritis and analgesic effect of ethanolic extract of the whole plant of Merremia emarginata Burm. F. Cent Eur J Exp Biol 2012;1:94-9.
167. Sharma V, Singh M. In vitro antiarthritic and hemolysis preventive: Membrane stabilizing efficacy of ethanolic root extract of Operculina turpethum. World J Pharm Pharm Sci 2013;2:302-12.

168. Kim KR, Chung TY, Shin H, Son SH, Park KK, Choi JH, et al. Red ginseng saponin extract attenuates murine collageninduced arthritis by reducing pro-inflammatory responses and matrix metalloproteinase-3 expression. Biol Pharm Bull 2010;33:604-10.

169. Malia SM, Sinnathambia A, Kapasea CU, Bodhankara SL, Mahadik KR. Anti-arthritic activity of standardised extract of Phyllanthus amarus in Freund's complete adjuvant-induced arthritis. Biomed Aging Pathol 2011;1:85-190.

170. Kumar SN, Kishore G, Kumar SG, Sindhu PE. In vitro antiinflammatory and anti-arthritic activity of leaves of Physalis angulata L. Int J Pharm Ind Res 2011;1:211-3.

171. Tsubata M, Takagaki K, Hirano S, Iwatani K, Abe C. Effects of flavangenol, an extract of French maritime pine bark on collagen-induced arthritis in rats. J Nutr Sci Vitaminol (Tokyo) 2011;57:251-7.

172. Pandey A, Bani S, Dutt P, Suri KA. Modulation of Th1/Th2 cytokines and inflammatory mediators by hydroxychavicol in adjuvant-induced arthritic tissues. Cytokine 2010;49:114-21.

173. Chauhan K, Solanki R, Patel A, Macwan C, Patel M. Phytochemical and therapeutic potential of Piper longum Linn: A review. Int J Res Ayur Pharm 2011;2:157-61.

174. Elumalai A, Prakash YG. Evaluation of the anti-arthritic activity of ethanolic extract of Pisonia grandis R.Br. Asian J Pharm Clin Res 2012;2:91-93.

175. Kyei S, Koffuor GA, Boampong JN. Antiarthritic effect of aqueous and ethanolic leaf extracts of Pistia stratiotes in adjuvant-induced arthritis in Sprague-Dawley rats. J Exp Pharmacol 2012;4:41-51.

176. Rajendran R, Krishnakumar E. Anti-arthritic activity of Premna serratifolia linn. wood against adjuvant induced arthritis. Avicenna J Med Biotechnol. 2010;2:101-6.

177. Georgewill AO, Georgewill UO. Antiarthritic activity of Pseudocdrea kotschyi in albino rats. Afr J Appl Zool Environ Biol 2008;10:70-72.

178. Shukla M, Gupta K, Rasheed Z, Khan KA, Haqqi TM. Consumption of hydrolyzable tannins-rich pomegranate extract suppresses inflammation and joint damage in rheumatoid arthritis. Nutrition 2008;24:733-743.

179. Lee JD, Huh JE, Jeon G, Yang HR, Woo HS, Choi DY, et al. Flavonolrich RVHxR from Rhus verniciflua stokes and its major compound fisetin inhibits inflammation-related cytokines and angiogenic factor in rheumatoid arthritic fibroblast-like synovial cells and in vivo models. Int Immunopharmacol 2009;9:268-276.

180. Ratheesh M, Shyni GL, Sindhu G, Helen A. Protective effects of isolated polyphenolic and alkaloid fractions of Ruta graveolens L. on acute and chronic models of inflammation. Inflammation 2010;33:18-24.

181. Sekiguchi Y, Mano H, Nakatani S, Shimizu J, Kobata K, Wada M. Anti-proliferative effects of Salacia reticulata leaves hotwater extract on interleukin-1ß-activated cells derived from the synovium of rheumatoid arthritis model mice. BMC Res Notes 2012;5:198.

182. Sharma S, Sahu D, Das HR, Sharma D. Amelioration of collageninduced arthritis by Salix nigra bark extract via suppression of proinflammatory cytokines and oxidative stress. Food Chem Toxicol 2011;49:3395-3406. 
183. Mukhopadhyay MK, Nath D. Phytochemical screening and toxicity study of Saraca asoca bark methanolic extract. Int J Phytomed 2011;3:498-405.

184. Saleem TS, Lokanath N, Prasanthi A, Madhavi M, Mallika G, Vishnu MN. Aqueous extract of Saussurea lappa root ameliorates oxidative myocardial injury induced by isoproterenol in rats. J Adv Pharm Technol Res 2013;4:94-100.

185. Ramprasath VR, Shanthi P, Sachdanandam P. Immunomodulatory and anti-inflammatory effects of Semecarpus Anacardium Linn. Nut milk extract in experimental inflammatory conditions. Biol Pharm Bull 2006;29:693-700.

186. Gupta SR, Nirmal SA, Patil RY, Asane GS. Anti-arthritic activity of various extracts of Sida rhombifolia aerial parts. Nat Prod Res 2009;23:689-695.

187. Liu L, Buchner E, Beitze D, Schmidt-Weber CB, Kaever V, Emmrich F, et al. Amelioration of rat experimental arthritides by treatment with the alkaloid sinomenine. Int J Immunopharmacol 1996; 18:529-543.

188. Endale M, Lee WM, Kwak YS, Kim NM, Kim BK, Kim SH, et al. Torilin ameliorates type II collagen-induced arthritis in a mouse model of rheumatoid arthritis. Int Immunopharmacol 2013;16:232-242.

189. Patil CR, Gadekar AR, Patel PN, Rambhade A, Surana SJ, Gaushal MH. Dual effect of Toxicodendron pubescens on Car- rageenan induced paw edema in rats. Homeopathy 2009;98:8891.

190. Sindhu G, Ratheesh M, Shyni GL, Nambisan B, Helen A. Antiinflammatory and antioxidative effects of mucilage of Trigonella foenum graecum (Fenugreek) on adjuvant-induced arthritic rats. Int Immunopharmacol 2012;12:205-211.

191. Abudoleh S, Disi A, Qunaibi E, Aburjai T. Anti-arthritic activity of the methanolic leaf extract of Urtica pilulifera L. on albino rats. Am J Pharmacol Toxicol 2011;6:27-32.

192. Choudhary S, Sharma M, Tripathi J, Mishra P. Antihyperglycemic activity of Vernonia cinerea L. on alloxan-induced diabetic mice. Int J Adv Res 2013;1:35-42.

193. Singh V, Patel H, Suvagiya V, Singh K. Some traditionally used antiarthritic herbs a review. Int Res J Pharm 2011;2:43-45.

194. Patil MV, Kandhare AD, Bhise SD. Anti-arthritic and anti-inflammatory activity of Xanthium srtumarium L. ethanolic extract in freund's complete adjuvant induced arthritis. Biomed Aging Pathol 2012;2:6-15.

195. Cheeke PR, Piacente S, Oleszek W. Anti-inflammatory and anti-arthritic effects of Yucca schidigera: A review. J Inflamm (Lond) 2006;3:6

Table 1: Traditionally used plants for treating Rheumatoid Arthritis

\begin{tabular}{|c|c|c|c|c|}
\hline Name of plant & Part used & Mode of use & Function & References \\
\hline Alpinia galangal & Rhizomes & $\begin{array}{l}\text { The paste of rhizome taken } \\
\text { orally }\end{array}$ & Gives relief in pain & 29 \\
\hline Anacyclus pyrethrum & Roots & $\begin{array}{l}\text { Infusion drink is taken like } \\
\text { tea of roots }\end{array}$ & $\begin{array}{l}\text { Anti-rheumatic \& } \\
\text { Anti-arthritic }\end{array}$ & 30 \\
\hline Aphanamixis polystachya & Bark & $\begin{array}{l}\text { Oil applied on joints to help } \\
\text { in pain }\end{array}$ & Act as analgesic & 31 \\
\hline Aquilaria agallocha & Wood & $\begin{array}{l}\text { Decoction taken of wood } \\
\text { and oil applied to help in } \\
\text { pain }\end{array}$ & $\begin{array}{l}\text { Relieve pain and } \\
\text { inflammation. }\end{array}$ & 32 \\
\hline Argemone mexicana & The whole plant, Latex & The oil used to help in pain & Cure rheumatologic. & 33 \\
\hline Callicarpa macrophylla & Flowers and fruits & Decoction taken & $\begin{array}{l}\text { Anti-inflammatory, } \\
\text { analgesic and antipy- } \\
\text { retic effects }\end{array}$ & 34 \\
\hline Capparis deciduas & Roots & Powder of infusion taken & $\begin{array}{l}\text { Treats rheumatism } \\
\text { and fever. }\end{array}$ & 35 \\
\hline Cardiospermum halicacabum & Roots & $\begin{array}{l}\text { The oil used to relieve pain } \\
\text { and powder taken orally }\end{array}$ & $\begin{array}{l}\text { Treats infection in } \\
\text { joints by trophic } \\
\text { organisms. }\end{array}$ & 36,37 \\
\hline Carthamus tinctorium & Seed & Infusion took orally & $\begin{array}{l}\text { Anti-inflammatory } \\
\text { and Analgesic. }\end{array}$ & 38,39 \\
\hline Cassia fistula & Fruits & $\begin{array}{l}\text { Infusion or paste of fruit } \\
\text { taken orally }\end{array}$ & Analgesic & 40 \\
\hline Catunaregum Spinosa & Bark & Paste or oil used & $\begin{array}{l}\text { It is useful in rheuma- } \\
\text { tism. }\end{array}$ & 41 \\
\hline Citrullus colocynthis & Roots & Powder of fruits taken orally & Anti-inflammatory. & 42 \\
\hline Commiphora myrrha & Gum & $\begin{array}{l}\text { Oil used for helping in pain } \\
\text { and taken gum taken orally }\end{array}$ & Relive in pain and & 43 \\
\hline Commiphora wightii & Leaves & Taken orally or infusion & $\begin{array}{l}\text { Relive in pain and } \\
\text { Anti-inflammatory }\end{array}$ & 44 \\
\hline
\end{tabular}


Table 1: (Continued)

\begin{tabular}{|c|c|c|c|c|}
\hline Name of plant & Part used & Mode of use & Function & References \\
\hline Cordia dichotoma & Fruits & $\begin{array}{l}\text { Taken orally or in form of } \\
\text { powder }\end{array}$ & Anti-rheumatic. & 45 \\
\hline Coriandrum sativum & Fruits and leaves & Taken orally & $\begin{array}{l}\text { Relive in pain and } \\
\text { Anti-inflammatory }\end{array}$ & 46 \\
\hline Euphorbia neriifolia & Leaf & Taken in form of juice orally & $\begin{array}{l}\text { Relieve pain in rheu- } \\
\text { matism }\end{array}$ & 47 \\
\hline Euphorbia ligularia & Whole plant & $\begin{array}{l}\text { Taken in the form of juice } \\
\text { or infusion }\end{array}$ & $\begin{array}{l}\text { Used in the treatment } \\
\text { of rheumatism. }\end{array}$ & 48,4 \\
\hline Ficus bengalensis & Latex & Taken as juice & $\begin{array}{l}\text { Used in the treatment } \\
\text { of rheumatism. }\end{array}$ & 50 \\
\hline Fritillaria roylei & Bulbs & $\begin{array}{l}\text { Taken in form of powder or } \\
\text { juice }\end{array}$ & $\begin{array}{l}\text { Used in the treatment } \\
\text { of rheumatism. }\end{array}$ & 51 \\
\hline Glycosmis Arborea & Roots & Taken in powder form & $\begin{array}{l}\text { Useful in the treat- } \\
\text { ment of arthritis. }\end{array}$ & 52 \\
\hline Gossypium herbaceum & Leaves & $\begin{array}{l}\text { Taken in powder form, juice } \\
\text { or infusion }\end{array}$ & $\begin{array}{l}\text { Relive in pain and } \\
\text { Anti-inflammatory. }\end{array}$ & 53 \\
\hline Heliotropium Indicum & Whole plant & $\begin{array}{l}\text { The oil used for joint pain } \\
\text { externally and other parts } \\
\text { are taken in powder form }\end{array}$ & $\begin{array}{l}\text { Gives positive results } \\
\text { against use for joint } \\
\text { inflammations }\end{array}$ & 54 \\
\hline Hiptage bengalensis & $\begin{array}{l}\text { Barks, Leaves and } \\
\text { Flowers }\end{array}$ & Taken in powder form & $\begin{array}{l}\text { Treatment of chronic } \\
\text { rheumatism }\end{array}$ & 55 \\
\hline Holarrhena pubescens & $\begin{array}{l}\text { Barks, Seeds and } \\
\text { Leaves }\end{array}$ & Taken in powder form & $\begin{array}{l}\text { Relive in pain and } \\
\text { Anti-inflammatory. }\end{array}$ & 56 \\
\hline Hygrophila auriculata & $\begin{array}{l}\text { Roots, Leaves and } \\
\text { Seeds }\end{array}$ & Taken in powder form & $\begin{array}{l}\text { Relive in pain and } \\
\text { Anti-inflammatory. }\end{array}$ & 57 \\
\hline Hyoscyamus niger & Leaves and Seeds & Taken in powder form & $\begin{array}{l}\text { Relive in pain and } \\
\text { Anti-inflammatory }\end{array}$ & 58 \\
\hline Illicium verum & Fruits & $\begin{array}{l}\text { Taken in powder form or } \\
\text { juice }\end{array}$ & $\begin{array}{l}\text { Relive in pain and } \\
\text { Anti-inflammatory. }\end{array}$ & 59 \\
\hline Inula racemosa & Roots & Taken orally in powder form & $\begin{array}{l}\text { Relive in pain and } \\
\text { Anti-inflammatory. }\end{array}$ & 60 \\
\hline Ipomoea cairica & Seeds & The oil used for pain & $\begin{array}{l}\text { Relive in pain and } \\
\text { Anti-inflammatory. }\end{array}$ & 61 \\
\hline Jasminum lanceolarium & Leaves and Flowers & $\begin{array}{l}\text { Taken in powder form or } \\
\text { juice }\end{array}$ & $\begin{array}{l}\text { Shows effective results } \\
\text { against rheumatism } \\
\text { and fever. On the } \\
\text { other hand, the leaves } \\
\text { have anti-inflamma- } \\
\text { tory properties and } \\
\text { relieve pain. }\end{array}$ & 62 \\
\hline Jatropha curcas & Oil & $\begin{array}{l}\text { The oil used for joint pain } \\
\text { externally }\end{array}$ & $\begin{array}{l}\text { Relive in pain and } \\
\text { Anti-inflammatory. }\end{array}$ & 63 \\
\hline Juglans regia & Fruits & $\begin{array}{l}\text { Taken in powder form or } \\
\text { juice }\end{array}$ & $\begin{array}{l}\text { Relive in pain and } \\
\text { Anti-inflammatory. }\end{array}$ & 64,65 \\
\hline Justicia gendarussa & Roots and Leaves & $\begin{array}{l}\text { Taken in powder form or } \\
\text { juice }\end{array}$ & $\begin{array}{l}\text { Relive in pain and } \\
\text { Anti-inflammatory. }\end{array}$ & 66 \\
\hline
\end{tabular}


Table 1: (Continued)

\begin{tabular}{|c|c|c|c|c|}
\hline Name of plant & Part used & Mode of use & Function & References \\
\hline Kaempferia galangal & Rhizomes and Leaves & $\begin{array}{l}\text { Taken orally in powder form } \\
\text { or juice }\end{array}$ & $\begin{array}{l}\text { Relive in pain and } \\
\text { Anti-inflammatory. }\end{array}$ & 67 \\
\hline Lantana Camara & Fruits & Taken orally & $\begin{array}{l}\text { Used traditionally for } \\
\text { the treatment of RA }\end{array}$ & 68 \\
\hline Lawsonia inermis & Leaves & $\begin{array}{l}\text { Taken orally in powder form } \\
\text { or infusion }\end{array}$ & $\begin{array}{l}\text { Used in arthritic } \\
\text { disorder. }\end{array}$ & 69 \\
\hline Lilium polyphyllum & Bulb & $\begin{array}{l}\text { Taken orally in powder form } \\
\text { or infusion }\end{array}$ & $\begin{array}{l}\text { Relive in pain and } \\
\text { Anti-inflammatory. }\end{array}$ & 70 \\
\hline Madhuca longifolia & Oil & $\begin{array}{l}\text { The oil used for joint pain } \\
\text { externally }\end{array}$ & $\begin{array}{l}\text { Relive in pain and } \\
\text { Anti-inflammatory. }\end{array}$ & 71 \\
\hline Mangifera indica & Roots and Barks & Taken in powder form & $\begin{array}{l}\text { Relive in pain and } \\
\text { Anti-inflammatory. }\end{array}$ & 72 \\
\hline Mimosa pudica & Whole plant & Taken orally & $\begin{array}{l}\text { Helps to deal with the } \\
\text { symptoms of rheuma- } \\
\text { toid arthritis. }\end{array}$ & 73 \\
\hline Momordica charantia & Fruits & $\begin{array}{l}\text { Taken orally if different } \\
\text { forms or as juice }\end{array}$ & $\begin{array}{l}\text { Relive in pain and } \\
\text { Anti-inflammatory. }\end{array}$ & 74 \\
\hline Myxopyrum serratulum & Leaves & Taken in powdered form & $\begin{array}{l}\text { Relive in pain and } \\
\text { Anti-inflammatory. }\end{array}$ & 75 \\
\hline Naravelia zeylanica & Whole plant & Taken in powder form & $\begin{array}{l}\text { Relive in pain and } \\
\text { Anti-inflammatory. }\end{array}$ & 76 \\
\hline Nilgirianthus ciliatus & Roots & Taken in powder form & $\begin{array}{l}\text { Relive in pain and } \\
\text { Anti-inflammatory. }\end{array}$ & 77 \\
\hline Ocimum basilicum & Whole plant & $\begin{array}{l}\text { Taken in form of infusion, } \\
\text { powder or leaves taken raw } \\
\text { orally }\end{array}$ & $\begin{array}{l}\text { Relive in pain and } \\
\text { Anti-inflammatory. }\end{array}$ & 78 \\
\hline Oroxylum Indicum & Roots & Taken in powder form & $\begin{array}{l}\text { The plant possesses } \\
\text { anti-inflammatory } \\
\text { activity. }\end{array}$ & 79 \\
\hline Pandanus odoratissimus & Oil & $\begin{array}{l}\text { The oil used for joint pain } \\
\text { externally }\end{array}$ & $\begin{array}{l}\text { Relive in pain and } \\
\text { Anti-inflammatory. }\end{array}$ & 80 \\
\hline Piper betel & Whole Plant & Orally in powdered form & $\begin{array}{l}\text { Shown effective results } \\
\text { in inflammation treat- } \\
\text { ment. }\end{array}$ & 81 \\
\hline Piper nigrum & Fruits & $\begin{array}{l}\text { Raw fruit used in cooking or } \\
\text { taken in powdered form }\end{array}$ & $\begin{array}{l}\text { Relive in pain and } \\
\text { Anti-inflammatory. }\end{array}$ & 82 \\
\hline Plumeria Rubra & Milky juice & $\begin{array}{l}\text { Applied externally to relieve } \\
\text { pain }\end{array}$ & $\begin{array}{l}\text { Shown positive results } \\
\text { in inflammation treat- } \\
\text { ment. }\end{array}$ & 83 \\
\hline Pongamia pinnata & Leaves & Taken in powder form & $\begin{array}{l}\text { Helps in painful rheu- } \\
\text { matic joints. }\end{array}$ & 84 \\
\hline Premna corymbosa & Leaves & Taken in powder form & $\begin{array}{l}\text { Relive in pain and } \\
\text { Anti-inflammatory }\end{array}$ & 85 \\
\hline Premna serratifolia & Whole plant & Taken orally & $\begin{array}{l}\text { Relive in pain and } \\
\text { Anti-inflammatory }\end{array}$ & 86 \\
\hline Ricinus communis & Leaves & Taken in powder form & $\begin{array}{l}\text { Relive in pain and } \\
\text { Anti-inflammatory }\end{array}$ & 87 \\
\hline Rubia cordifolia & Roots & Taken in powder form & $\begin{array}{l}\text { Relive in pain and } \\
\text { Anti-inflammatory }\end{array}$ & 88 \\
\hline
\end{tabular}


Table 1: (Continued)

\begin{tabular}{|c|c|c|c|c|}
\hline Name of plant & Part used & Mode of use & Function & References \\
\hline Ruta chalepensis & Oil & $\begin{array}{l}\text { The oil used for joint pain } \\
\text { externally }\end{array}$ & $\begin{array}{l}\text { Analgesic, antipyretic, } \\
\text { anti-inflammatory } \\
\text { and relieves rheumatic } \\
\text { pain. }\end{array}$ & 89 \\
\hline Sida cordifolia & Roots and Leaves & Taken in powder form & $\begin{array}{l}\text { Used for treating } \\
\text { rheumatism. }\end{array}$ & 90 \\
\hline Solanum nigrum & Whole Plant & $\begin{array}{l}\text { Taken in powder form } \\
\text { Taken in powder form }\end{array}$ & $\begin{array}{l}\text { Relive in pain and } \\
\text { Anti-inflammatory }\end{array}$ & 91 \\
\hline Spondias pinnata & Roots & & $\begin{array}{l}\text { Relive in pain and } \\
\text { Anti-inflammatory } \\
\text { and helps in muscular } \\
\text { pain in rheumatism }\end{array}$ & 92 \\
\hline Stereospermum colais & Leaves & Taken in powder form & $\begin{array}{l}\text { Relive in pain and } \\
\text { Anti-inflammatory }\end{array}$ & 93 \\
\hline Tectona grandis & Wood & $\begin{array}{l}\text { Taken in powder form, the } \\
\text { oil used for external use }\end{array}$ & $\begin{array}{l}\text { Used in treating in- } \\
\text { flammatory swelling. }\end{array}$ & 94 \\
\hline Trachyspermum Ammi & Fruits & $\begin{array}{l}\text { Taken in powder or juice } \\
\text { form of fresh fruit }\end{array}$ & $\begin{array}{l}\text { Relive in pain and } \\
\text { Anti-inflammatory }\end{array}$ & 95 \\
\hline Tribulus Terrestris & Whole Plant & $\begin{array}{l}\text { used for joint pain exter- } \\
\text { nally }\end{array}$ & $\begin{array}{l}\text { Used for external ap- } \\
\text { plication in rheumat- } \\
\text { ic-arthritis. }\end{array}$ & 96 \\
\hline Vatteria indica & Oil & $\begin{array}{l}\text { The oil used for joint pain } \\
\text { externally }\end{array}$ & $\begin{array}{l}\text { Relive in pain and } \\
\text { Anti-inflammatory }\end{array}$ & 97 \\
\hline Vitex negundo & Roots & Taken in powder form & $\begin{array}{l}\text { Relive in pain and } \\
\text { Anti-inflammatory }\end{array}$ & 98 \\
\hline Vitis vinifera & Stem & $\begin{array}{l}\text { Taken in powder form or } \\
\text { infusion }\end{array}$ & $\begin{array}{l}\text { Relive in pain and } \\
\text { Anti-inflammatory }\end{array}$ & 99 \\
\hline
\end{tabular}

Table 2: Experimentally proven plants for Rheumatoid Arthritis

\begin{tabular}{|c|c|c|c|c|}
\hline Name of the plant & Common name & Type of Extract used & Activity observed & Reference \\
\hline Achyranthes Aspera & Apamaraga & Ethanol & $\begin{array}{l}\text { Prevented the recruitment of } \\
\text { leukocytes }\end{array}$ & 100,101 \\
\hline $\begin{array}{l}\text { Aconitum } \\
\text { vilmorinianum }\end{array}$ & Wolf's-bane, & Ethanol & $\begin{array}{l}\text { Improvement of joint swelling } \\
\text { and vascular permeability }\end{array}$ & 102 \\
\hline Ajuga bracteosa & Ground pine & Ethanol & COX-1 and COX-2 inhibition & 103 \\
\hline Ajuga decumbens & Bugle weed & Ethanol & $\begin{array}{l}\text { Regulates the balance between } \\
\text { bone formation and bone resorp- } \\
\text { tion }\end{array}$ & 104 \\
\hline Alstonia boonei & Cheese wood & Methanol & $\begin{array}{l}\text { Relief in early and late phase of } \\
\text { pain }\end{array}$ & 105 \\
\hline Alstonia scholaris & $\begin{array}{l}\text { devil } \\
\text { tree }\end{array}$ & Ethanol & $\begin{array}{l}\text { Shown activity in Reduction of } \\
\text { total leukocyte, lymphocytes and } \\
\text { monocytes/ } \\
\text { macrophages migration }\end{array}$ & 106 \\
\hline Ammania bracifera & tooth cup & $\begin{array}{l}\text { Aqueous Alcoholic Pe- } \\
\text { troleum Ether, Chloro- } \\
\text { form, Methanol }\end{array}$ & Decrease the ESR and WBC count & 107 \\
\hline $\begin{array}{l}\text { Aristolochia } \\
\text { bracteata }\end{array}$ & Kidamari & $\begin{array}{l}\text { Petroleum Ether, Chlo- } \\
\text { roform, Methanol }\end{array}$ & $\begin{array}{l}\text { It maintains vascular permeabil- } \\
\text { ity and synovial membrane and } \\
\text { with inhibition of cytokines and } \\
\text { leukotriene infiltration }\end{array}$ & 108 \\
\hline 27 & & & Cur Res Rev | Vol 13 • Issue 03 • F & ary 2021 \\
\hline
\end{tabular}


Table 2: (Continued)

\begin{tabular}{|c|c|c|c|c|}
\hline Name of the plant & Common name & Type of Extract used & Activity observed & Reference \\
\hline Argyreia speciosa & $\begin{array}{l}\text { Elephant } \\
\text { Creeper }\end{array}$ & $\begin{array}{l}\text { Methanol, } \\
\text { Ethanol }\end{array}$ & $\begin{array}{l}\text { Prevented the recruitment of } \\
\text { leukocytes }\end{array}$ & 100,109 \\
\hline $\begin{array}{l}\text { Arisaema } \\
\text { rhizomatum }\end{array}$ & Jack in the pulp it & Methanol & $\begin{array}{l}\text { Have shown result against pro- } \\
\text { inflammatory cytokines and RA } \\
\text { factor secretion }\end{array}$ & 110 \\
\hline Arnebia euchroma & Pink arnebia & Ethanol (95\%) & $\begin{array}{l}\text { Suppression of IL-1 } \beta \text { and TNF- } \alpha \\
\text { levels }\end{array}$ & 111 \\
\hline $\begin{array}{l}\text { Artocarpus } \\
\text { tonkinensis }\end{array}$ & Chay & Ethyl acetate & $\begin{array}{l}\text { Apoptosis induction in activated } \\
\text { T-cells }\end{array}$ & 112 \\
\hline Asystasia dalzelliana & Violet asystasia & Ethanol & $\begin{array}{l}\text { Decreasing synthesis/release of } \\
\text { T-cell } \\
\text { mediators }\end{array}$ & 113 \\
\hline $\begin{array}{l}\text { Baccharis } \\
\text { genistelloides }\end{array}$ & Carqueja & Aqueous & $\begin{array}{l}\text { Suppresses synovial fibroblast } \\
\text { proliferation and induced pro- } \\
\text { duction of progelatinase B and } \\
\text { PGE2 }\end{array}$ & 114 \\
\hline Bacopa monniera & $\begin{array}{l}\text { Herpestis mon- } \\
\text { niera }\end{array}$ & Methanol & $\begin{array}{l}\text { Stabilizing action on lysosomal } \\
\text { membranes }\end{array}$ & 115 \\
\hline Barleria lupulina & Hophead & Methanol & $\begin{array}{l}\text { Assisting cell mediated immune } \\
\text { responses }\end{array}$ & 116 \\
\hline Barleria prionitis & Katsareya & Hydro-ethanolic & $\begin{array}{l}\text { Lowers the ESR level and have an } \\
\text { immuno-modulatory activity }\end{array}$ & 117 \\
\hline Bauhinia variegate & Kachnar & Ethanol & $\begin{array}{l}\text { Alteration in antioxidant en- } \\
\text { zymes such as catalase, superox- } \\
\text { ide dismutase and glutathione } \\
\text { peroxidase }\end{array}$ & 118,119 \\
\hline Bergenia stracheyi & Paashaanbhed & $\begin{array}{l}\text { Petroleum Ether, Chlo- } \\
\text { roform }\end{array}$ & $\begin{array}{l}\text { Potential Th1/Th2 cytokine bal- } \\
\text { ancing activity }\end{array}$ & 120 \\
\hline Boerhaavia diffusa & Punarnava & Petroleum Ether & $\begin{array}{l}\text { Inhibition of inflammatory } 7 \\
\text { inhibitor }\end{array}$ & 121 \\
\hline Boswellia carterii & Olibanum & n-Hexane & $\begin{array}{l}\text { Formation of } \mathrm{LTB}_{4} \text { leukotriene is } \\
\text { reduced } \\
\text { As well as infiltration of leuco- } \\
\text { cytes altered }\end{array}$ & 122 \\
\hline Butea monosperma & Palash & Petroleum Ether & $\begin{array}{l}\text { Hemoglobin and RBC level was } \\
\text { increased while; WBC, ESR level } \\
\text { were suppressed }\end{array}$ & 123,124 \\
\hline Caesalpinia sappan & Sapanwood & Ethanol & $\begin{array}{l}\text { Showed Inhibitory the expression } \\
\text { of TNF- } \alpha \text { and pro-inflammatory } \\
\text { cytokines IL-1ß }\end{array}$ & 125 \\
\hline Calotropis gigantean & Milkweed & Petroleum Ether & $\begin{array}{l}\text { Pro-inflammatory cytokines are } \\
\text { reduced }\end{array}$ & 126 \\
\hline Calatropis procera & Sodom apple & Methanol & $\begin{array}{l}\text { Inhibit cellular influx and vas- } \\
\text { cular } \\
\text { permeability }\end{array}$ & 127 \\
\hline Caltha palustris & Kingcup & Methanol & $\begin{array}{l}\text { Absolute count and percent- } \\
\text { age of splenic T-regulatory cells } \\
\mathrm{CD}_{4}+\mathrm{CD}_{25}+\mathrm{FOXP}_{3} \text { was reduced }\end{array}$ & 128 \\
\hline Cannabis sativum & Ganja & Alcoholic & Diminished IFN- $\gamma$ production & 129 \\
\hline
\end{tabular}


Table 2: (Continued)

\begin{tabular}{|c|c|c|c|c|}
\hline Name of the plant & Common name & Type of Extract used & Activity observed & Reference \\
\hline $\begin{array}{l}\text { Capparis } \\
\text { erythrocarpus }\end{array}$ & Flamingo & Ethanol & $\begin{array}{l}\text { Inhibit the release of pro-inflam- } \\
\text { matory } \\
\text { cytokines }\end{array}$ & 130 \\
\hline Capparis spinosa & Flinders rose & Hydro-alcoholic & Counteract the effects of IL-1 & 131 \\
\hline $\begin{array}{l}\text { Cardiospermum } \\
\text { halicacabum }\end{array}$ & Ballon plant & Ethanol & $\begin{array}{l}\text { CFA Histamine and prostaglan- } \\
\text { din synthesis } \\
\text { inhibition }\end{array}$ & 132 \\
\hline Cayaponia tayuya & Tayuya & Hydro-alcoholic & $\begin{array}{l}\text { Modify the expression of both } \\
\text { COX-2 and nitric oxide syn- } \\
\text { thase-2. Decreases production of } \\
\text { IL-1 } \beta \text { \& TNF- } \alpha \text { in lymphocytes }\end{array}$ & 133 \\
\hline Cassia uniflora & One leaf senna & $\begin{array}{l}\text { Methanol, Petroleum } \\
\text { Ether, Ethyl Acetate }\end{array}$ & $\begin{array}{l}\text { Reduction of CRP and RF levels } \\
\text { in the serum }\end{array}$ & 134 \\
\hline Celastrus aculeatus & Gua shan fena & Ethanol & $\begin{array}{l}\text { CFA down regulate the biochemi- } \\
\text { cal and immunological mediator }\end{array}$ & 135 \\
\hline Centella asiatica & Brahmi & Methanol & $\begin{array}{l}\text { Have inhibitory activity against } \\
\text { protein denaturation and mem- } \\
\text { brane stabilization }\end{array}$ & 136 \\
\hline $\begin{array}{l}\text { Cinnammomum } \\
\text { zeylcanium }\end{array}$ & Dalchini & Aqueous & $\begin{array}{l}\text { Inhibition of leukocyte emigra- } \\
\text { tion }\end{array}$ & 137 \\
\hline Cissampelos pareira & Butua & $50 \%$ aqueous:ethanol & $\begin{array}{l}\text { Acid phosphatase and } \mathrm{N} \text {-acetyl } \\
\text { glucosaminidase were reduced } \\
\text { while hexose and sialic acid } \\
\text { increased. }\end{array}$ & 138 \\
\hline Chelidonium majus & Tetterwort & Methanol & $\begin{array}{l}\text { Decreased number of } \mathrm{CD} 4+\mathrm{T} \\
\text { cells in lymph node and spleen, } \\
\text { immunosuppression by lower- } \\
\text { ing the CD } 4+\mathrm{T} \text {-cells and enhance } \\
\text { CD8+T-cells. }\end{array}$ & 139 \\
\hline Cleome gyandra & Shone cabbage & Ethanol & $\begin{array}{l}\text { CFA modifying the lysosomal } \\
\text { membrane thus Inhibiting lyso- } \\
\text { somal enzymes release }\end{array}$ & 140 \\
\hline Coriandrum sativum & Cilantro & Hydro-alcoholic & $\begin{array}{l}\text { Inhibit the secretion of pro-in- } \\
\text { flammatory cytokines including } \\
\text { TNF- } \alpha \text {. }\end{array}$ & 141 \\
\hline Costus speciosus & Keukand & Methanol & $\begin{array}{l}\text { Suppression of inflammatory } \\
\text { mediators }\end{array}$ & 142 \\
\hline Curcuma longa & Turmeric & n-Hexane & $\begin{array}{l}\text { Activation of genes critical to } \\
\text { articular } \\
\text { inflammation }\end{array}$ & 143 \\
\hline Curcuma zeodaria & White turmeric & $\begin{array}{l}\text { Chloroform, Petroleum } \\
\text { Ether }\end{array}$ & $\begin{array}{l}\text { Decrease the latency time to } \\
\text { explore }\end{array}$ & 144 \\
\hline Delonix elata & Gulmohar & $\begin{array}{l}\text { Petroleum Ether, Chlo- } \\
\text { roform, Hydroalcoholic }\end{array}$ & $\begin{array}{l}\text { Blocking the action of COX, LO } \\
\text { and AT and thus preventing the } \\
\text { generation of mediators }\end{array}$ & 145 \\
\hline Dipsacus asperoides & Japanese teasel & Aqueous & $\begin{array}{l}\text { Reduced the levels of anti-CII } \\
\text { IgG2a antibody, PGE2, TNF- } \alpha \text { and } \\
\text { IL-1 } \beta\end{array}$ & 146 \\
\hline Drynaria quercifolia & Oak & Aqueous & Inhibition of ROS release & 147 \\
\hline $\begin{array}{l}\text { Elaecarpus } \\
\text { sphaericus }\end{array}$ & $\begin{array}{l}\text { Blue marble } \\
\text { Tree }\end{array}$ & Ethanol & $\begin{array}{l}\text { Inhibition of leukocytes migra- } \\
\text { tion at the site of inflammation }\end{array}$ & 148 \\
\hline
\end{tabular}


Table 2: (Continued)

\begin{tabular}{|c|c|c|c|c|}
\hline Name of the plant & Common name & Type of Extract used & Activity observed & Reference \\
\hline Ephedra sinica & Ma Haung & Aqueous & $\begin{array}{l}\text { Expressions of TNF- } \alpha \text { and IL- } 6 \\
\text { genes restored to normal levels in } \\
\text { experimental arthritis }\end{array}$ & 149 \\
\hline $\begin{array}{l}\text { Euphorbia } \\
\text { antiquorum }\end{array}$ & Antique spurge & Methanol & $\begin{array}{l}\text { Arachidonic metabolites and } \\
\text { cell-mediated immunity was sup- } \\
\text { pressed }\end{array}$ & 150 \\
\hline Ficus bengalensis & Banyan tree & Methanol & $\begin{array}{l}\text { Inhibition of the early phase of } \\
\text { inflammation }\end{array}$ & 151 \\
\hline Ginkgo biloba & $\begin{array}{l}\text { Maiden hair } \\
\text { tree }\end{array}$ & Methanol & $\begin{array}{l}\text { Macrophages infiltrated to the } \\
\text { the inflamed site was inhibited } \\
\text { for NO production }\end{array}$ & 152 \\
\hline $\begin{array}{l}\text { Glycosmis } \\
\text { pentaphylla }\end{array}$ & Orange berry & Ethanol & $\begin{array}{l}\text { Increased in haematological pa- } \\
\text { rameters like RBC count, Hb level } \\
\text { and the ESR }\end{array}$ & 153 \\
\hline Glycyrrhiza glabra & Liquorice & Methanol & $\begin{array}{l}\text { Lysosomal membrane stability } \\
\text { increased and inhibiting leuko- } \\
\text { cyte migration }\end{array}$ & 154 \\
\hline Hedera helix & European ivy & Ethanol, hydro-ethanolic & Reduction in arthritic symptoms & 155 \\
\hline Hemidesmus indicus & $\begin{array}{l}\text { Indian } \\
\text { Sarsaparilla }\end{array}$ & Hydro-ethanolic & $\begin{array}{l}\text { Inhibition of bradykinin, cara- } \\
\text { genin and serotonin concentra- } \\
\text { tion in inflammation }\end{array}$ & 156 \\
\hline Hippocratea excels & Mata piojo & Ethanol & $\begin{array}{l}\text { Shows activity against both the } \\
\text { proliferative phase and exudative } \\
\text { phase of inflammation }\end{array}$ & 157 \\
\hline $\begin{array}{l}\text { Hybanthus } \\
\text { enneaspermus }\end{array}$ & $\begin{array}{l}\text { Humpback } \\
\text { flower }\end{array}$ & Aqueous, Ethanol & $\begin{array}{l}\text { Inhibits the release of proinflam- } \\
\text { mmatory cytokines (IL-1 } \beta \text { and } \\
\text { TNF- } \alpha \text { ) and decrease GM-CSF, } \\
\text { PDGF and IFN- } \gamma \text { production }\end{array}$ & 158 \\
\hline Justicia gendarussa & $\begin{array}{l}\text { Willow leaved } \\
\text { justice }\end{array}$ & Ethanol & $\begin{array}{l}\text { Inhibition of migration of leuko- } \\
\text { cytes }\end{array}$ & 159 \\
\hline Lantana camara & & Ethanol & $\begin{array}{l}\text { Lipoxygenase and/or cyclooxy- } \\
\text { genase } \\
\text { Inhibition }\end{array}$ & 160 \\
\hline Laportea bulbifera & Mukago-irakusa & Ethanol & $\begin{array}{l}\text { Decreased production of IFN- } \gamma \\
\text { and IL-2, and increased produc- } \\
\text { tion of IL-10 and TGF- } \beta\end{array}$ & 161 \\
\hline Lawsonia inermis & Henna & $\begin{array}{l}70 \% \text { aqueous ethyl } \\
\text { alcohol }\end{array}$ & $\begin{array}{l}\text { Decrease in inflammatory media- } \\
\text { tors to suppress both acute and } \\
\text { chronic phase } \\
\text { of inflammation }\end{array}$ & 162 \\
\hline Leucas aspera & Thumbai & $\begin{array}{l}\text { n-hexane, } \\
\text { Chloroform, } \\
\text { Ethyl Acetate, Ethanol }\end{array}$ & $\begin{array}{l}\text { Decreased levels of CRP, TNF- } \alpha \\
\text { and IL-2 } \\
\text { And the complete formation of } \\
\text { cartilage }\end{array}$ & 163 \\
\hline Linum usitatissimum & Flax & Petroleum Ether & $\begin{array}{l}\text { FIA Inhibitory effect on arachido- } \\
\text { nate metabolism }\end{array}$ & 164 \\
\hline Lonicera japonica & $\begin{array}{l}\text { Japanese honey } \\
\text { Suckle }\end{array}$ & Methanol & Suppress T-cell proliferation & 165 \\
\hline $\begin{array}{l}\text { Merremia } \\
\text { emarginata }\end{array}$ & Kupit-kupit & Ethanol & $\begin{array}{l}\text { Restores body weight and Im- } \\
\text { proves ESR, hemoglogin values }\end{array}$ & 166 \\
\hline
\end{tabular}


Table 2: (Continued)

\begin{tabular}{|c|c|c|c|c|}
\hline Name of the plant & Common name & Type of Extract used & Activity observed & Reference \\
\hline Operculina turpethum & Turpeth & Ethanol & $\begin{array}{l}\text { Inhibit the denaturation of } \\
\text { proteins }\end{array}$ & 167 \\
\hline Panax ginseng & Ginseng & Ethanol & $\begin{array}{l}\text { Suppressed TPA-induced acute } \\
\text { inflammation }\end{array}$ & 168 \\
\hline Phyllanthus amarus & Chanca & Aqueous & ALT and IT levels were reduced & 169 \\
\hline Physalis angulate & Fisalia & $\begin{array}{l}\text { Aqueous, Ethanol, } \\
\text { Methanol }\end{array}$ & $\begin{array}{l}\text { Inhibit the denaturation of } \\
\text { proteins }\end{array}$ & 170 \\
\hline Pinus maritime & Maritime pine & Hydro-ethanolic & $\begin{array}{l}\text { Inhibits acute and chronic in- } \\
\text { flammatory } \\
\text { lesions }\end{array}$ & 171 \\
\hline Piper betle & Tambula & Hydro-ethanolic & $\begin{array}{l}\text { Reduced levels of } \mathrm{CD}_{4}+\mathrm{T} \text { cell } \\
\text { specific IFN- } \gamma \text { in splenocytes. }\end{array}$ & 82,172 \\
\hline Piper longum & Pippali & Aqueous & $\begin{array}{l}\text { Neutrophils adherence to } \\
\text { endothelial monolayer was } \\
\text { inhibited due to TNF- } \alpha \text { induced } \\
\text { ICAM-1,VCAM- } 1 \text { and E-selectin } \\
\text { expression inhibition and also } \\
\text { reduced activation of NF-kB }\end{array}$ & 173 \\
\hline Pisonia grandis & Devil's-claws & Ethanol & $\begin{array}{l}\text { IFN, GM-CSF and PGDF cy- } \\
\text { tokines are suppressed in CFA } \\
\text { induced mediators }\end{array}$ & {$[174]$} \\
\hline Pistia stratiotes & Water lettuce & Aqueous, Ethanol & $\begin{array}{l}\text { Low levels of C-reactive proteins } \\
\text { and ESR }\end{array}$ & 175 \\
\hline Premna serratifolia & Agnimantha & Ethanol & $\begin{array}{l}\text { Suppression of migration of } \\
\text { leukocytes }\end{array}$ & 176 \\
\hline Pseudocdrea kotschyi & Hard cedar & Aqueous & $\begin{array}{l}\text { Reduction in inflammation due } \\
\text { to mediators } \\
\text { suppression }\end{array}$ & 177 \\
\hline Punica granatum & Pomegranate & Aqueous & $\begin{array}{l}\text { Inhibition of the spectrum of the } \\
\text { signal transduction pathway }\end{array}$ & 178 \\
\hline Rhus verniciflua & $\begin{array}{l}\text { Chinese lacquer } \\
\text { Tree }\end{array}$ & n-hexane & $\begin{array}{l}\text { In IL-1 } \beta \text {-stimulated RA, inflam- } \\
\text { matory } \\
\text { cytokines/chemokines and angio- } \\
\text { genic factor were suppressed }\end{array}$ & 179 \\
\hline Ruta graveolens & Rue & Aqueous & $\begin{array}{l}\text { Reduces cell influx, the release of } \\
\text { mediators, } \\
\text { lipid peroxidation and oxidative } \\
\text { stress }\end{array}$ & 180 \\
\hline Salacia reticulate & $\begin{array}{l}\text { Khothala } \\
\text { himbutu }\end{array}$ & Ethanol & $\begin{array}{l}\text { Inhibitory affect against regula- } \\
\text { tion of mRNA expression and } \\
\text { IL-1 } \beta \text { - activated cell proliferation }\end{array}$ & 181 \\
\hline Salix nigra & Black willow & Methanol & $\begin{array}{l}\text { Inhibition of pro inflammatory } \\
\text { inhibitor }\end{array}$ & 182 \\
\hline Saraca asoca & Ashoka & Methanol & $\begin{array}{l}\text { Stabilizing effect on lysosomal } \\
\text { membrane, ths reduced acid } \\
\text { hydrolase release. Have Antago- } \\
\text { nistic action to the pro-inflam- } \\
\text { matory cytokines }\end{array}$ & 183 \\
\hline Saussurea lappa & Kuth & Ethanol & $\begin{array}{l}\text { InLPS-stimulated murine mac- } \\
\text { rophage cell line, TNF- } \alpha \text { release } \\
\text { was inhibited }\end{array}$ & 184 \\
\hline
\end{tabular}


Table 2: (Continued)

\begin{tabular}{|c|c|c|c|c|}
\hline Name of the plant & Common name & Type of Extract used & Activity observed & Reference \\
\hline $\begin{array}{l}\text { Semecarpus } \\
\text { Anacardium }\end{array}$ & Bhallatak & Aqueous, Ethanol & Inhibition of cytokine production & 185 \\
\hline Sida rhombifolia & Cuban jute & $\begin{array}{l}\text { Methanol, Petroleum } \\
\text { Ether }\end{array}$ & $\begin{array}{l}\text { Generation of reactive oxygen } \\
\text { species was } \\
\text { suppressed }\end{array}$ & 186 \\
\hline Sinomenium acutum & Tudurafuji & Alcoholic & $\begin{array}{l}\text { Inhibition of lymphocyte prolif- } \\
\text { eration and } \\
\text { macrophage }\end{array}$ & 187 \\
\hline Torilis japonica & $\begin{array}{l}\text { Upright hedge } \\
\text { Parsley }\end{array}$ & Methanol & $\begin{array}{l}\text { Inhibitory effects on } \mathrm{CD}_{4} \mathrm{~T} \text {-cells } \\
\text { immune cell trafficking. }\end{array}$ & 188 \\
\hline $\begin{array}{l}\text { Toxicodendron } \\
\text { pubescens }\end{array}$ & Atlantic poison & Aqueous & Immunosuppressant activity & 189 \\
\hline Trigonella foenum & Fenugreek & Aqueous & $\begin{array}{l}\text { Reduces cell influx, mediators } \\
\text { release and oxidative stress }\end{array}$ & 190 \\
\hline Urtica pilulifera & Roman nettle & Methanol & Suppress the activation of NF-kB & 191 \\
\hline Vernonia cinerea & Bitter leaf ndole & Ethanol & $\begin{array}{l}\text { Membrane stability-modulating } \\
\text { effect }\end{array}$ & 192 \\
\hline Withania somnifera & $\begin{array}{l}\text { Indian winter } \\
\text { Cherry }\end{array}$ & Hydro-alcoholic & $\begin{array}{l}\text { Inhibiting the release of inflam- } \\
\text { matory } \\
\text { mediators }\end{array}$ & 193 \\
\hline Xanthium srtuarium & Datura & Ethanol & $\begin{array}{l}\text { Inflammatory mediators were in- } \\
\text { hibited, NO level decreased and } \\
\text { infiltration of urinary hydroxy- } \\
\text { proline and neutrophil }\end{array}$ & 194 \\
\hline Yucca schidigera & Spanish dagger & Hydro-alcoholic & Inhibition of NFkB activation & 195 \\
\hline
\end{tabular}

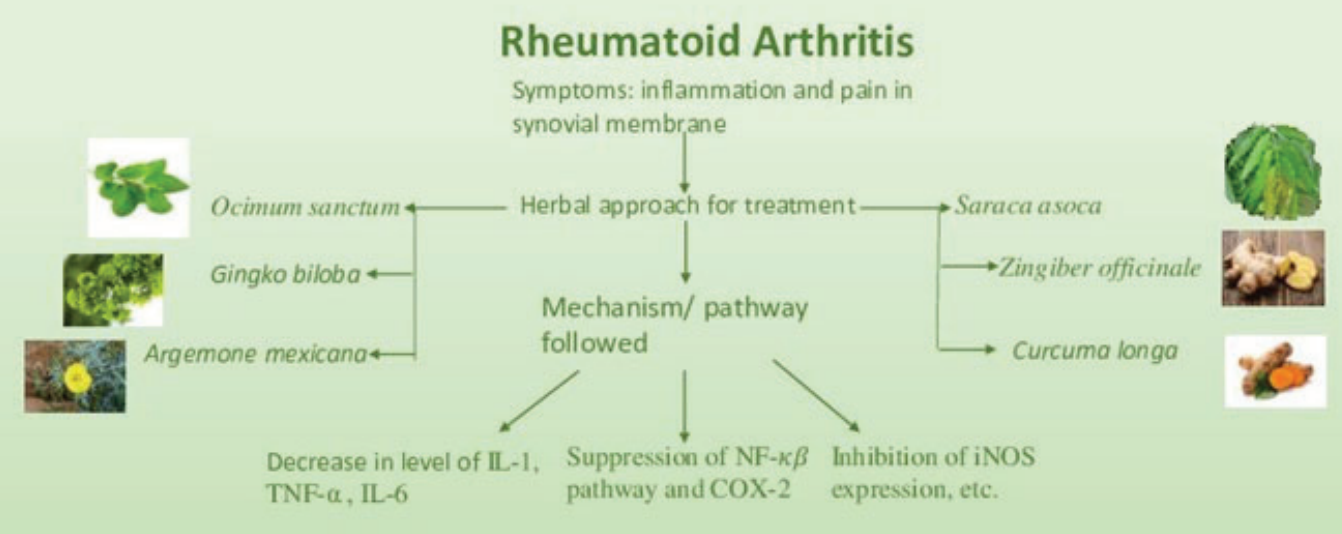

Graphical Abstract 